\title{
sciendo
}

\author{
Current Issues in Pharmacy and Medical Sciences
}

Formerly ANNALES UNIVERSITATIS MARIAE CURIE-SKIODOWSKA, SECTIO DDD, PHARMACIA

journal homepage: http://www.curipms.umlub.pl/

\section{Fatty acid composition of night-scented stock (Matthiola bicornis (Sibth. \& Sm.) DC.) raw materials}

\author{
Viktorita O. Pinkevych ${ }^{1 \star} \oplus$, Moeen F. Dababneh $^{2} \odot$, \\ Nadita Ye. Burda ${ }^{1}{ }^{1}$, Iryna O. Zhuravel ${ }^{1}{ }^{\circledR}$
}

\begin{abstract}
${ }^{1}$ National University of Pharmacy, Kharkiv, Ukraine
${ }^{2}$ Middle East University, Amman, Jordan
\end{abstract}

\section{ARTICLE INFO}

Received 14 August 2020

Accepted 20 December 2020

\section{Keywords:}

Matthiola bicornis

(Sibth. \& Sm.) DC.,

fatty acids,

gas chromatography.

\begin{abstract}
Introduction. With due consideration of the properties of fatty acids, as well as their importance for normal life activity and human development, research into the fatty acid composition of poorly studied plants and the search for new domestic plant sources of polyunsaturated fatty acids is a mainstream trend in modern pharmacy.

Aim. Aim of research - determination of fatty acid qualitative composition and content in threshed grass, stalks, roots and seeds of Night-scented stock 'Queen of Night' and 'Evening Scent' cultivars as grown in Ukraine.

Methods. Gas chromatography.

Results. Both cultivars of Night-scented stock taken for analysis had similar fatty acid composition - 5 saturated, 5 ( 4 for seeds) monounsaturated and 2 polyunsaturated fatty acids, Quantitatively, in all tested parts of the herb polyunsaturated and monounsaturated fatty acid dominated, making in total $88.92 \%$ and $88.62 \%$ in the seeds of Queen of Night and Evening Scent cultivars, respectively, and averaging 65\% in other parts of the tested cultivars. Linolenic and linoleic acids prevailed among the polyunsaturated fatty acids, whereas oleic acid prevailed among the monounsaturated.

Conclusion. Night-scented stock can be utilized as a source of polyunsaturated fatty acids for the development of drugs and for standardization of tested raw materials.
\end{abstract}

\section{INTRODUCTION}

Among the most important nutrients ensuring the normal development and balance maintenance between the physiological and pathological processes in the organism we may note the fatty acids [1-4]. They are the structural components of phospholipids, sphingolipids, cardiolipin, triglycerides, cholesterol esters, as well as the predecessors of eicosanoids (bioactive tissue hormones) such as prostaglandins, leukotrienes, thromboxanes, lipoxin, prostacyclins and hydroxyeicosatetraenoic acids [2,5-7].Recently, special attention has been paid to polyunsaturated fatty acids. First of all, because such acids as linoleic, linolenic, arachidonic, eicosapentaenoic and docosahexaenoic, are indispensable $[2,5,7]$ Secondly, data from contemporary sources specify their possession of a wide range of pharmacological activities, namely, antiatherogenic [3-7], antiaggregant [3,6-8], antithrombotic $[3,5,6]$, angioprotective [6], hypolipidemic $[3,6,8]$, anti-inflammatory $[3,6-8]$, cardioprotective $[1,4,5,8]$,

\footnotetext{
* Corresponding author

e-mail: vikapinkevych@gmail.com
}

antiarrhythmogenic [1,6-8], antihypertensive [3,6-8] and anti-carcinogenic $[3,9,10]$. Thus, polyunsaturated fatty acids have wide application for both preventing and treating variegated diseases, whereas their deficit may provoke several illnesses and pathological states.

With due consideration of the properties of fatty acids, their importance for normal vital activity and development of the human organism, the study of fatty acid composition of poorly explored plants and the search for new domestic plant sources of polyunsaturated fatty acids is one of the advanced trends in modern pharmacy.

In this regard, plants of the Matthiola species are worth exploiting. Indeed, judging from foreign literature sources, Matthiola species plants (in particular, Matthiola incana (L.) R. Br., Matthiola bicornis (Sibth. \& Sm.) DC., Matthiola annua (L.) Sweet, Matthiola longipetala subsp. bicornis (Sibth. \& Sm.) P.W. Ball) possess high content and variegated qualitative composition of fatty acids [11-14].

Night-scented stock (Matthiola bicornis (Sibth. \& Sm.) DC.) is widely cultivated all over Ukraine as a decorative 
plant, but we lack data on the fatty acid composition of Ukraine-grown herbs.

\section{AIM}

The aim of the present research is to determine the fatty acid composition of night-scented stock herb cultivated in Ukraine.

\section{MATERIALS AND METHODS}

The objects of our study were stalk-threshed grass, stalks, roots harvested during blooming, as well as seeds of Night-scented stock, particularly, the cultivars Tsarytsia Nochi (Queen of Night) and Vechirnii Aromat (Evening Scent). The herbs were harvested in July-August 2019. The plants were identified by the Department of Chemistry of natural compounds and Nutriciology, National University of Pharmacy, Kharkiv, Ukraine. Voucher specimens of the plants were deposited in the Departmental Herbarium for future record.

Fatty acid composition of tested herbs was studied via gas chromatography, using a method based on the formation of fatty acids methyl esters with subsequent determination of each one.

In the analysis, $0.5 \mathrm{~g}$ (accurately mass) of dried and powdered raw materials was selected and placed in a glass vial. Subsequently, $3.3 \mathrm{~cm}^{3}$ of the reaction mixture (methanol-toluene-sulfuric acid (44:20:2) and $1.7 \mathrm{~cm}^{3}$ of an internal standard in heptane solution were added. The sample was then maintained at a temperature of $80^{\circ} \mathrm{C}$ for $2 \mathrm{hrs}$ to completely remove the lipophilic fraction from the plant material and to induce hydrolysis of fatty oils into fatty acids and their methylation products. After this, the sample was cooled to room temperature and centrifuged for $10 \mathrm{~min}$ at $5000 \mathrm{rpm}$. Thereafter, $0.5 \mathrm{~cm}^{3}$ of the upper heptane phase containing fatty acid methyl esters was taken $[15,16]$.

Methyl esters of fatty acids were studied using a Selmichrom-1 (JSC Selmi) gas chromatograph equipped with flame ionization detector and a $2.5 \mathrm{~m}$ long stainless steel gas chromatography column (Restek Inc.) with $4 \mathrm{~mm}$ inside diameter filled with a sta-

Table 1. Fatty acid composition of Night-scented stock herb

\begin{tabular}{|c|c|c|c|c|c|c|c|c|c|c|}
\hline \multirow{2}{*}{ № } & \multirow{2}{*}{$\begin{array}{c}\text { Brief } \\
\text { designation }\end{array}$} & \multirow{2}{*}{$\begin{array}{c}\text { Name } \\
\text { of fatty acid }\end{array}$} & 1 & 2 & 3 & 4 & 5 & 6 & 7 & 8 \\
\hline & & & \multicolumn{8}{|c|}{ Content, $\%$ of total } \\
\hline 1 & C $14: 0$ & $\begin{array}{l}\text { myristic } \\
\text { acid }\end{array}$ & 0.30 & 5.71 & 0.44 & 0.10 & 0.18 & 6.05 & 0.58 & 0.43 \\
\hline 2 & C $14: 1(\omega-5)$ & $\begin{array}{l}\text { myristoleic } \\
\text { acid }\end{array}$ & 0.08 & 0.10 & 0.25 & 0.22 & 0.08 & 0.25 & 0.30 & 0.49 \\
\hline 3 & C $16: 0$ & $\begin{array}{l}\text { palmitic } \\
\text { acid }\end{array}$ & 7.17 & 17.59 & 26.46 & 28.22 & 7.84 & 18.80 & 27.97 & 33.04 \\
\hline 4 & C $16: 1(\omega-7)$ & $\begin{array}{l}\text { palmitoleic } \\
\text { acid }\end{array}$ & 0.12 & 0.88 & 0.67 & 0.43 & 0.05 & 1.13 & 1.15 & 0.58 \\
\hline 5 & \multicolumn{2}{|l|}{ *_--* } & 0.20 & - & - & - & 0.23 & - & - & - \\
\hline 6 & C $18: 0$ & $\begin{array}{l}\text { stearic } \\
\text { acid }\end{array}$ & 3.13 & 0.83 & 1.55 & 3.18 & 2.85 & 1.50 & 3.00 & 3.96 \\
\hline 7 & C $18: 1(\omega-9)$ & $\begin{array}{l}\text { oleic } \\
\text { acid } \\
\end{array}$ & 15.85 & 11.05 & 9.40 & 11.65 & 15.10 & 8.93 & 8.95 & 13.65 \\
\hline 8 & C $18: 2(\omega-6)$ & $\begin{array}{l}\text { linoleic } \\
\text { acid }\end{array}$ & 11.60 & 14.85 & 26.48 & 36.04 & 9.64 & 13.74 & 24.25 & 29.35 \\
\hline 9 & C $18: 3(\omega-3)$ & \begin{tabular}{|l|} 
linolenic \\
acid \\
\end{tabular} & 61.20 & 38.84 & 31.35 & 17.65 & 63.70 & 35.77 & 28.62 & 14.88 \\
\hline 10 & C $20: 1(\omega-9)$ & $\begin{array}{l}\text { gondoic } \\
\text { acid }\end{array}$ & - & 1.08 & 0.35 & 0.10 & - & 1.47 & 0.15 & 0.27 \\
\hline 11 & C $22: 0$ & \begin{tabular}{|l|} 
docosanoic \\
acid
\end{tabular} & 0.08 & 0.33 & 0.74 & 1.20 & 0.05 & 0.35 & 0.75 & 2.10 \\
\hline 12 & C $22: 1(\omega-9)$ & erucic acid & 0.07 & 1.24 & 0.23 & 0.20 & 0.05 & 2.80 & 1.29 & 0.43 \\
\hline 13 & \multicolumn{2}{|c|}{$* *_{--} * *$} & 0.10 & - & - & 0.20 & 0.15 & - & - & 0.20 \\
\hline 14 & \multicolumn{2}{|c|}{$* * *$ ** } & - & 5.52 & 1.15 & - & - & 5.47 & 1.15 & - \\
\hline 15 & C $24: 0$ & \begin{tabular}{|l|} 
lignoceric \\
acid
\end{tabular} & 0.10 & 0.18 & 0.45 & 0.81 & 0.08 & 0.19 & 0.22 & 0.62 \\
\hline 16 & \multicolumn{2}{|c|}{$* * *_{--} * *$} & - & 1.80 & 0.48 & - & - & 3.55 & 1.62 & - \\
\hline \multicolumn{3}{|c|}{\begin{tabular}{|l|} 
Total unidentified fatty acids \\
\end{tabular}} & 0.30 & 7.32 & 1.63 & 0.20 & 0.38 & 9.02 & 2.77 & 0.20 \\
\hline \multicolumn{3}{|c|}{ Total saturated fatty acids } & 10.78 & 24.64 & 29.64 & 33.51 & 11.00 & 26.89 & 32.52 & 40.15 \\
\hline \multicolumn{3}{|c|}{ Total unsaturated fatty acids } & 88.92 & 68.04 & 68.73 & 66.29 & 88.62 & 64.09 & 64.71 & 59.65 \\
\hline \multicolumn{3}{|c|}{ - monounsaturated } & 16.12 & 14.35 & 10.90 & 12.60 & 15.28 & 14.58 & 11.84 & 15.42 \\
\hline \multicolumn{3}{|c|}{ - polyunsaturated } & 72.80 & 53.69 & 57.83 & 53.69 & 73.34 & 49.51 & 52.87 & 44.23 \\
\hline \multicolumn{3}{|c|}{ Grand total: } & 100.00 & 100.00 & 100.00 & 100.00 & 100.00 & 100.00 & 100.00 & 100.00 \\
\hline \multicolumn{3}{|c|}{\begin{tabular}{|l|}
$\begin{array}{l}\text { Total unsaturated/total } \\
\text { saturated }\end{array}$ \\
\end{tabular}} & 8.2 & 2 & 2 & 1.98 & 8 & 2.38 & 1.99 & 1.49 \\
\hline \multicolumn{3}{|c|}{$\begin{array}{l}\begin{array}{l}\text { Total saturated/total } \\
\text { unsaturated }\end{array} \\
\end{array}$} & 0.12 & 0.36 & 0.43 & 0.51 & 0.12 & 0.42 & 0.50 & 0.67 \\
\hline \multicolumn{3}{|c|}{$\omega-6 / \omega-3$ ratio } & $1: 5,28$ & $1: 2,61$ & $1: 1,18$ & $1: 0,49$ & $1: 6,61$ & $1: 2,60$ & $1: 1,18$ & $1: 0,51$ \\
\hline
\end{tabular}

*-* unidentified components; 1 - Night-scented stock - Queen of Night seeds; 2 - Night-scented stock - Queen of Night threshed grass; 3 - Night-scented stock - Queen of Night stalks; 4 - Nightscented stock - Queen of Night roots; 5 - Night-scented stock - Evening Scent seeds; 6 - Nightscented stock - Evening Scent threshed grass; 7 - Night-scented stock - Evening Scent stalks; 8 - Night-scented stock - Evening Scent roots standard samples. Compositions of fatty acid methyl esters were calculated by applying the inner normalization method. Reference samples were standards of saturated and unsaturated fatty acid methyl esters $[15,16]$. All applied reagents Sigma Aldrich Chemical Company.

\section{RESULTS AND DISCUSSION}

Chromatograms of tested herb fatty acid composition determination are shown in Figures 1-8. The results of study in qualitative composition and quantitative contents of fatty acid in Night-scented stock herbs, cultivars Queen of Night and Evening Scent, are shown in the table. were of the highest purity available and purchased from the tionary phase of $10 \%$ diethylene glycol succinate (DEGS)treated inerton.

The following chromatography parameters were established: sample introduction $-2 \mathrm{~mm}^{3}$ under splitless mode; introduction rate $-1.2 \mathrm{~cm}^{3} / \mathrm{min}$ within $0.2 \mathrm{~min}$, thermostat temperature of columns $-180^{\circ} \mathrm{C}$; evaporator temperature $230^{\circ} \mathrm{C}$; detector temperature $-220^{\circ} \mathrm{C}$; carrier gas (nitrogen) flow velocity $-30 \mathrm{~cm}^{3} / \mathrm{min}[15,16]$. Fatty acid methyl esters were identified by peak retention times as compared with 


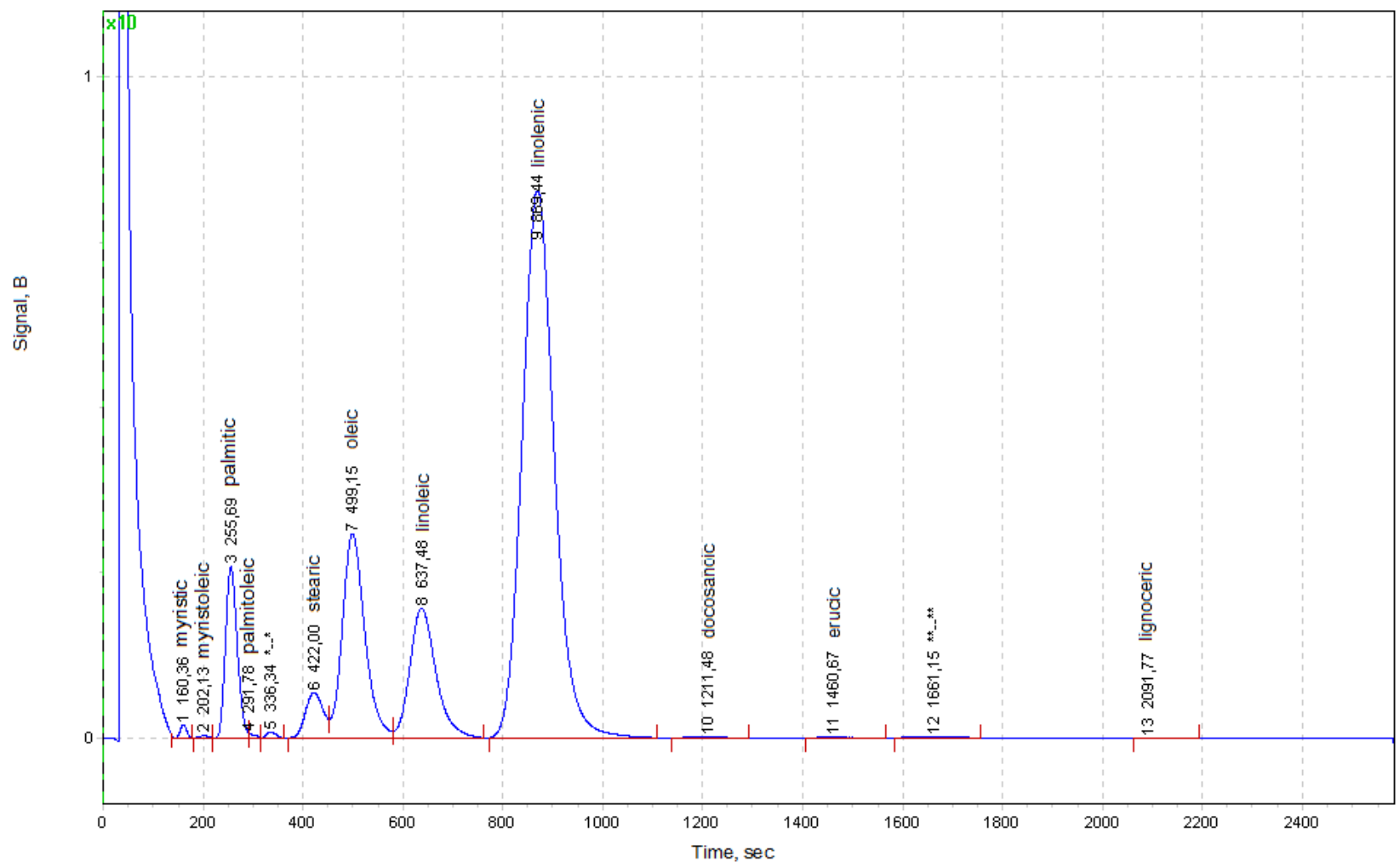

Figure 1. Fatty acid composition determination chromatogram of Night-scented stock - Queen of Night seeds

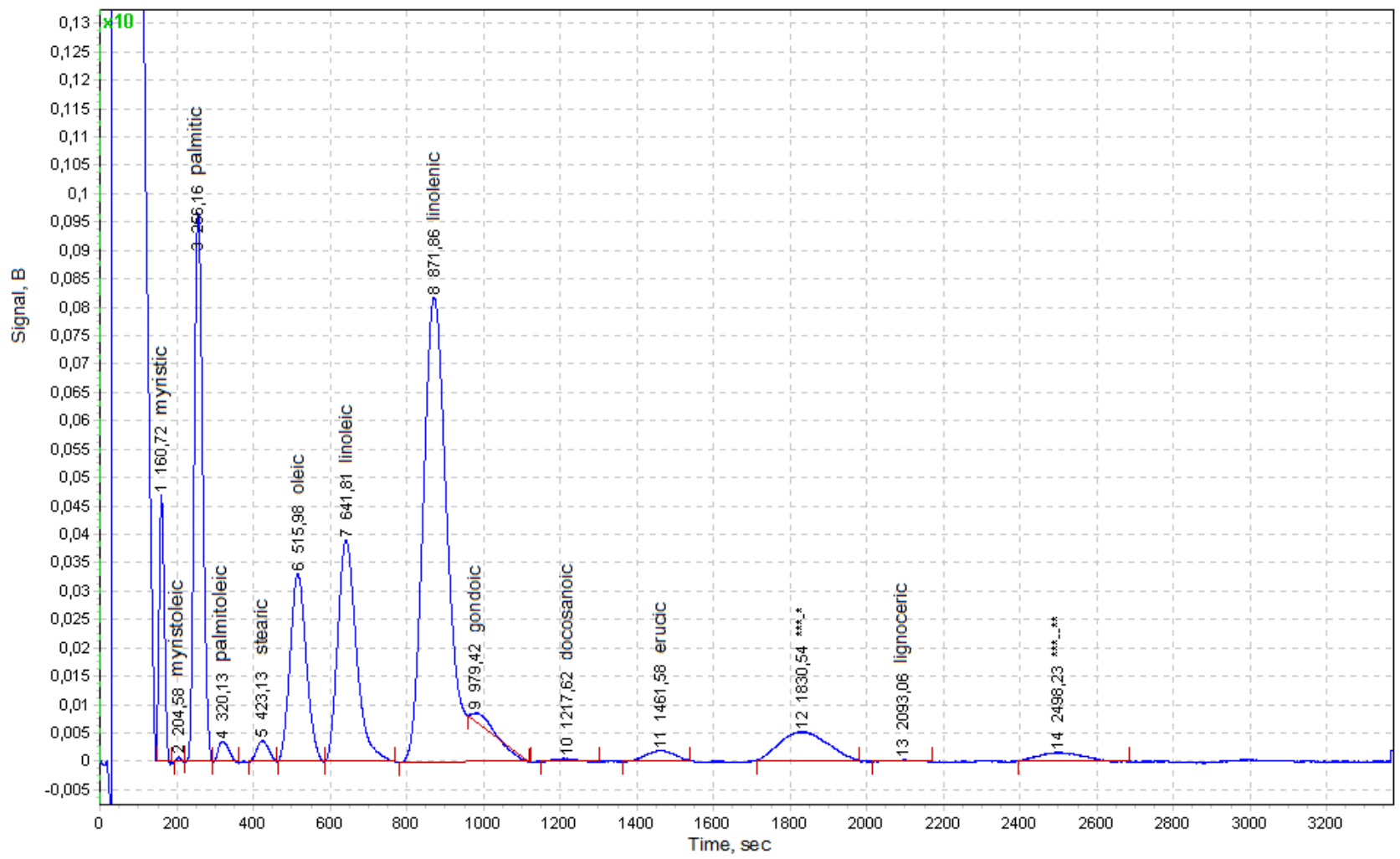

Figure 2. Fatty acid composition determination chromatogram of Night-scented stock - Queen of Night threshed grass 


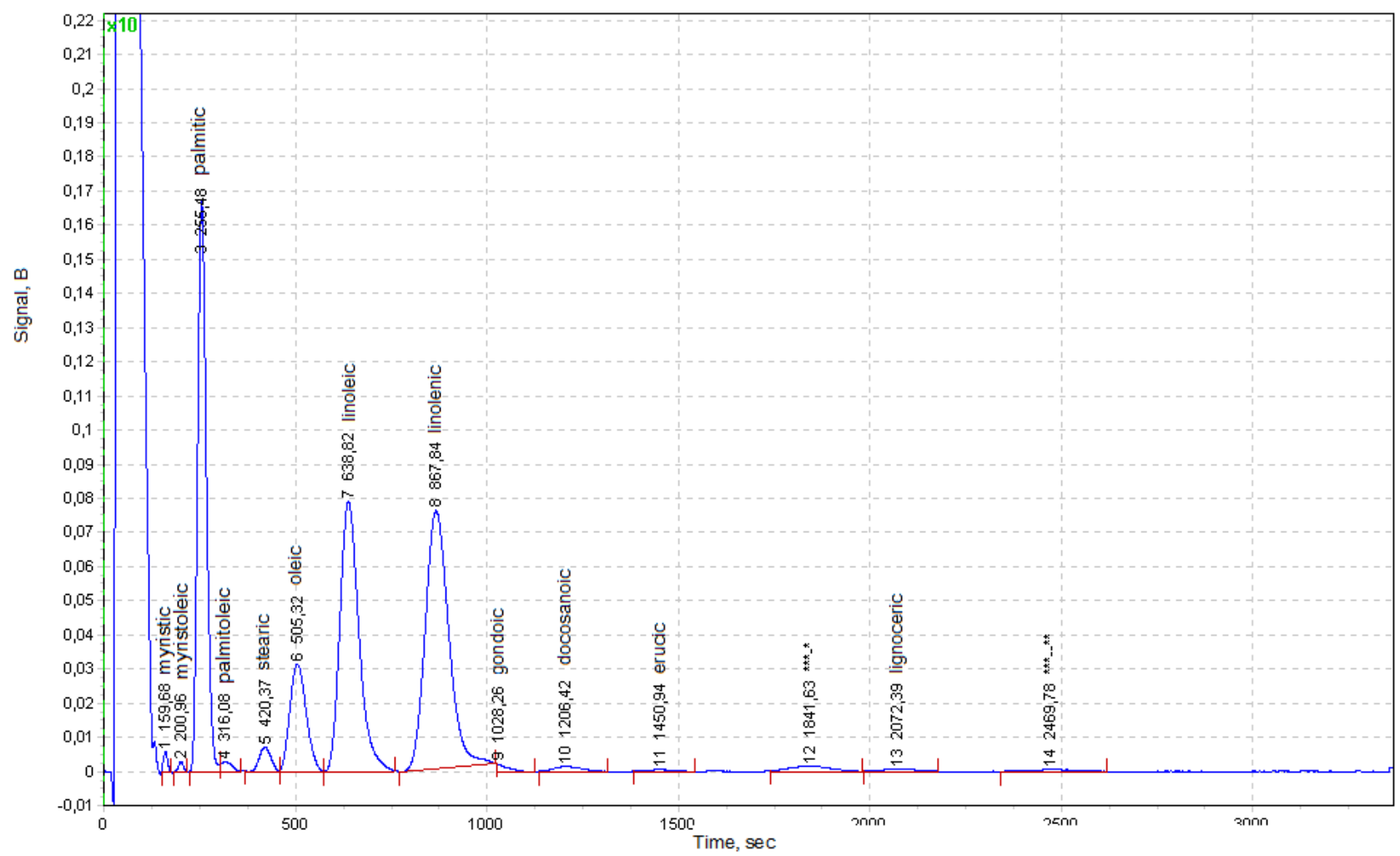

Figure 3. Fatty acid composition determination chromatogram of Night-scented stock - Queen of Night stalks

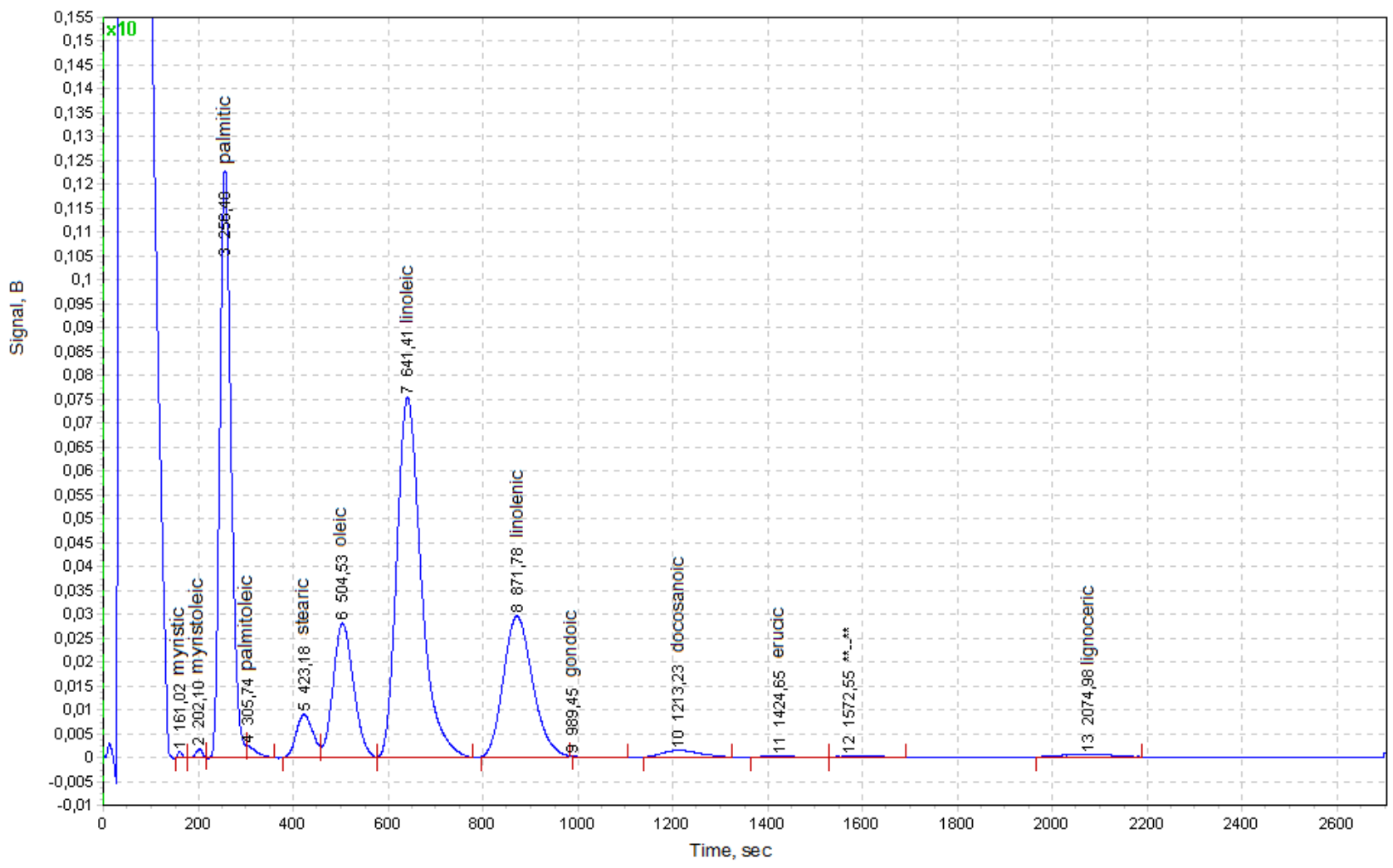

Figure 4. Fatty acid composition determination chromatogram of Night-scented stock - Queen of Night roots 


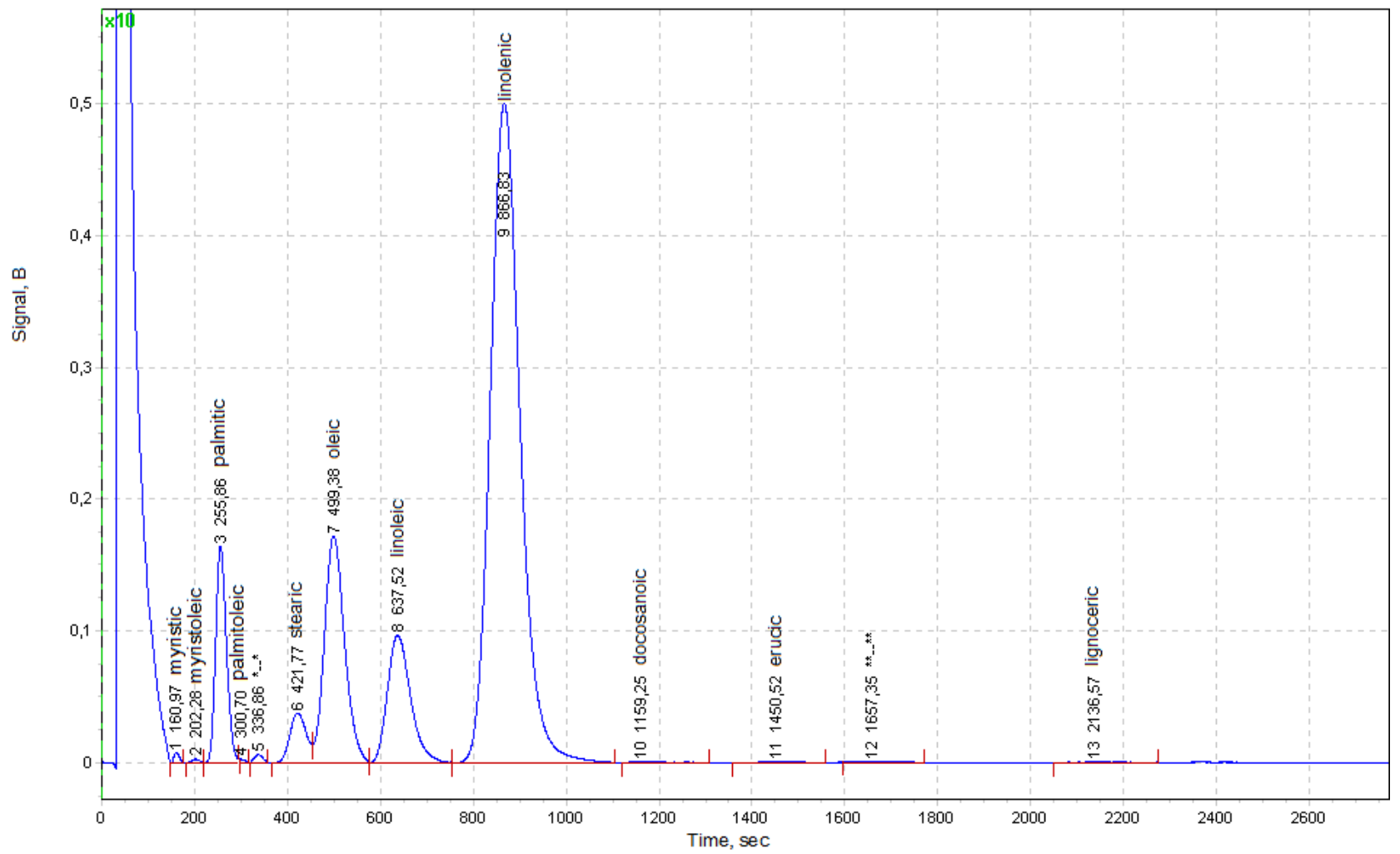

Figure 5. Fatty acid composition determination chromatogram of Night-scented stock - Evening Scent seeds

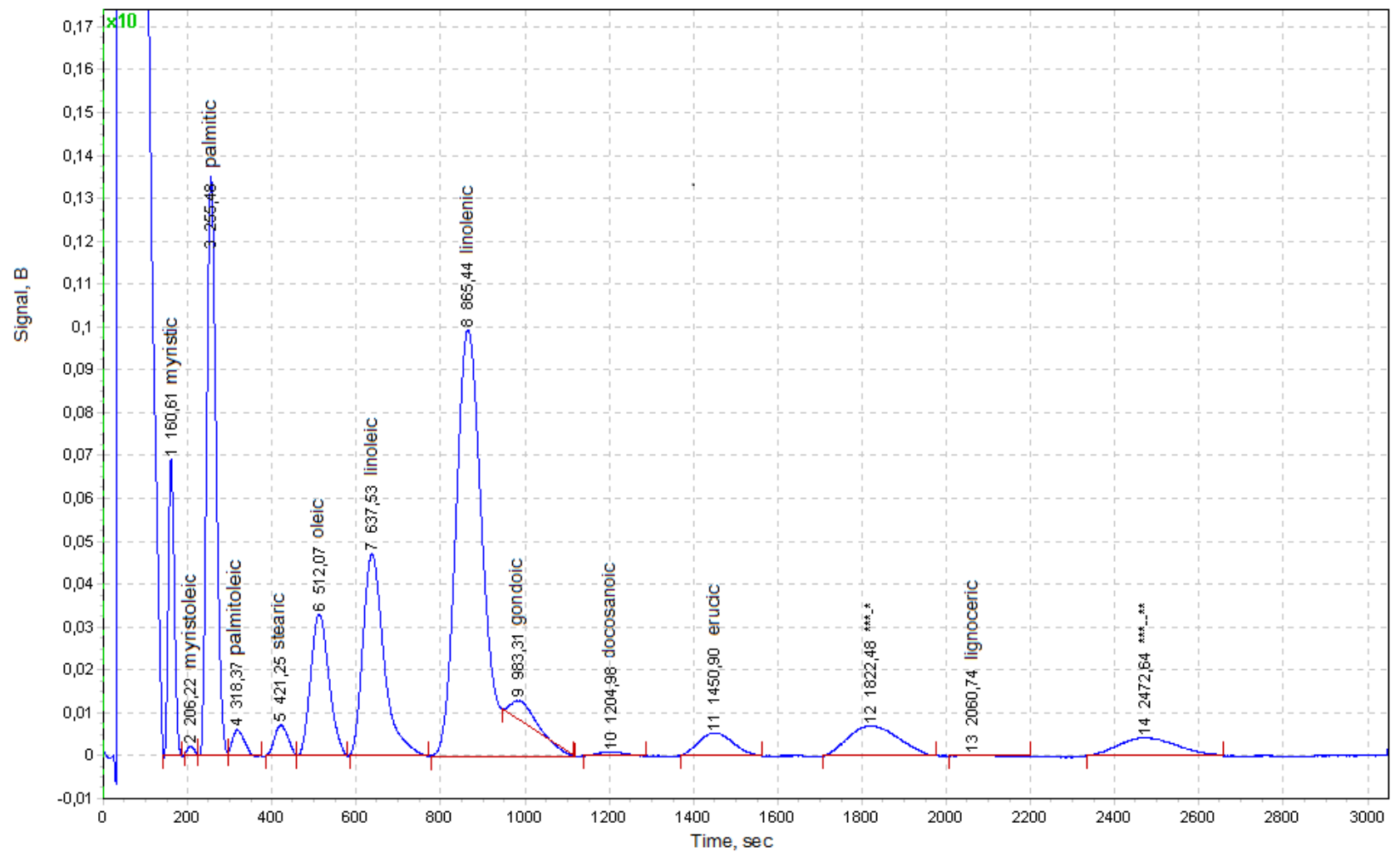

Figure 6. Fatty acid composition determination chromatogram of Night-scented stock - Evening Scent threshed grass 


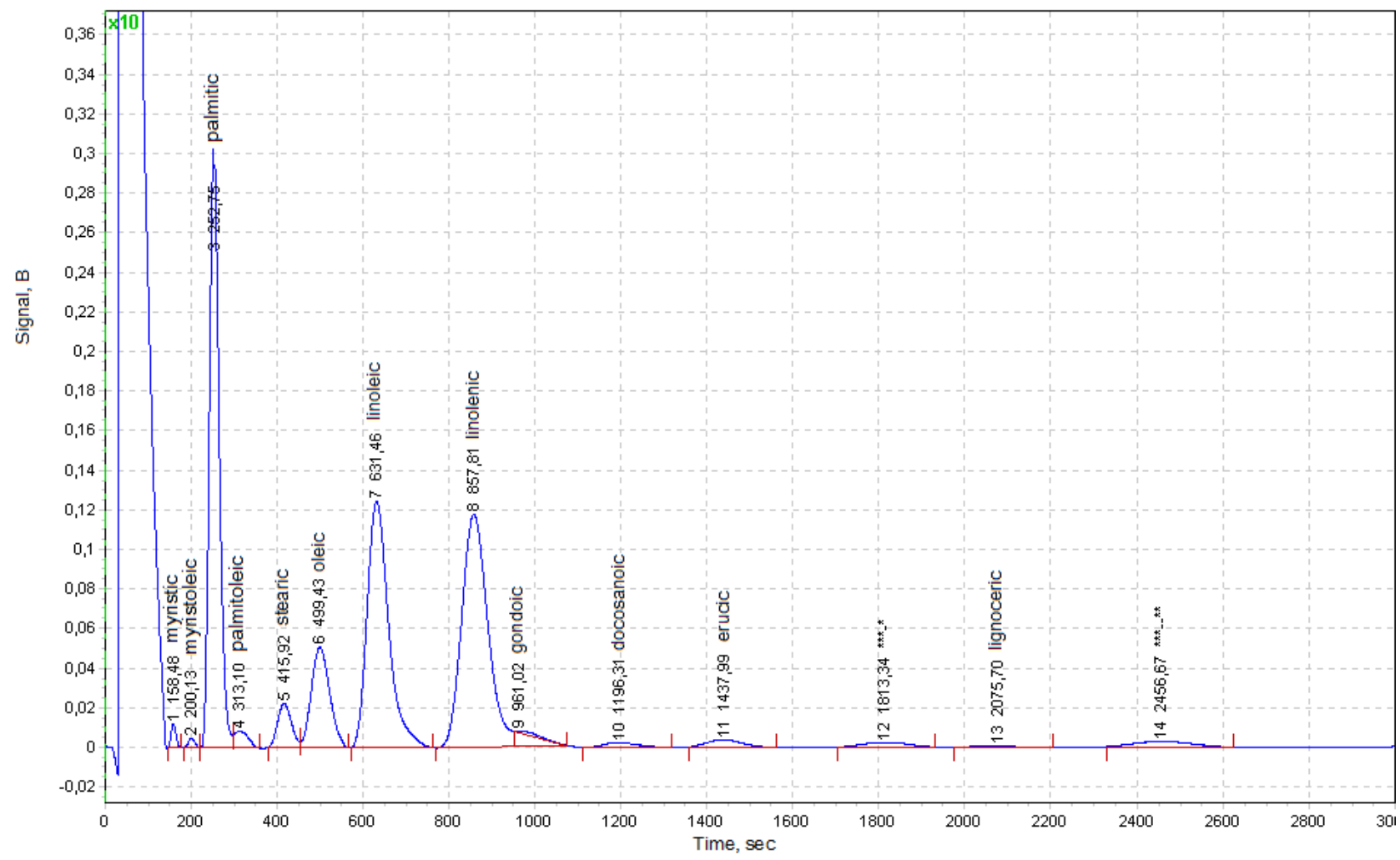

Figure 7. Fatty acid composition determination chromatogram of Night-scented stock - Evening Scent stalks

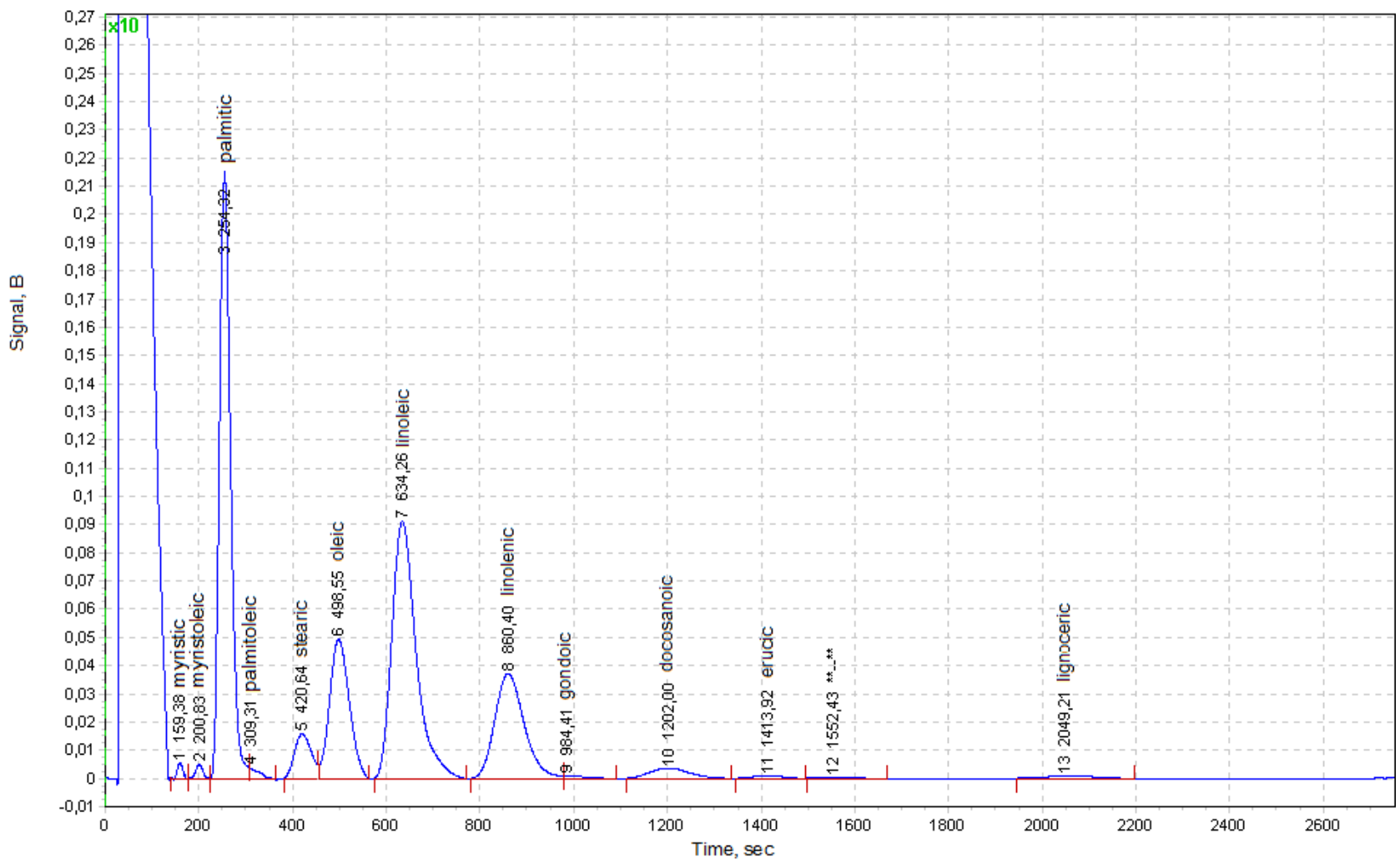

Figure 8. Fatty acid composition determination chromatogram of Night-scented stock - Evening Scent roots 
In all tested types of herb, polyunsaturated fatty acids substantially prevailed: in elevated parts - linolenic acid (its content in Queen of Night seeds was 61.20\%, in Evening Scent seeds $-63.70 \%$, in threshed grass $-38.84 \%$ and $35.77 \%$, in stalks $-31.35 \%$ and $28.62 \%$, respectively), in the underground parts - linoleic acid (36.04\% in Queen of Night roots, $29.35 \%$ in Evening Scent roots). Linolenic acid content in seeds was, therefore, 1.5-2 times higher than in threshed grass and stalks and 3-4 times higher than in roots. A comparison of quantitative content of this fatty acid in the Night-scented stock herb cultivars showed that the threshed grass, stalks and roots of Queen of Night contained somewhat more of this acid than that in the similar parts of Evening Scent, whereas the pattern was vice versa in the seeds. As regards linoleic acid, all parts of Queen of Night have somewhat higher content than that of Evening Scent. Its content in the roots was thrice higher than in the seeds, twice higher than in the threshed grass and 1.3 higher than in the stalks.

Among monounsaturated fatty acids, oleic acid dominated, being at least $15 \%$ in seeds and at least $8.9 \%$ in all other tested parts of the Night-scented stock cultivars. As regards the content of this fatty acid, Queen of Night had more of it in the seeds, threshed grass and stalks, whereas Evening Scent had greater content in the roots. We found as little as $1.15 \%$ palmitoleic acid in the threshed grass and stalks, $0.7 \%$ in the roots and $0.12 \%$ in the seeds of both cultivars, whereas myristoleic acid content never exceeded $0.5 \%$ in all samples. Gondoic acid was not identified in the seeds of either cultivar, its amount in the threshed grass was within the limits of $1-1.5 \%$, in the stalks and roots -0.1 $0.4 \%$. The content of erucic acid in the seeds and roots of both cultivars, as well as the stalks of Queen of Night did not exceed $0.5 \%$, while in the threshed grass of both cultivars and in the stalks of Evening Scent, this did not exceed 3\%.

Among the identified saturated fatty acids, palmitic acid was of greatest content. In the Evening Scent cultivar, this was somewhere higher than in the other cultivar and was at $7.17 \%$ in Queen of Night seeds as compared to $7.84 \%$ in Evening Scent seeds (and respectively, 17.59\% and 18.80\% in threshed grass, $26.46 \%$ and $27.97 \%$ in stalks, $28.22 \%$ and $33.04 \%$ in roots).

The myristic acid content in the threshed grass was $5.71 \%$ for Queen of Night and 6.05\% for Evening Scent cultivar, whereas in other parts of this herb it never exceeded $0.6 \%$. Stearic acid content in seeds, stalks and roots was below $4 \%$, and below $1.6 \%$ in the threshed grass. Docosanoic (behenic) acid was mostly accumulated in the below ground parts $(1.20 \%$ in the roots of Queen of Night and $2.10 \%$ in that of Evening Scent), while its content decreased successively in the stalks/threshed grass/seeds and was actually identical for both cultivars.

Comparative analysis of the fatty acid composition showed that Evening Scent contained more stearic, palmitoleic, myristic, myristoleic and erucic acid in the threshed grass, stalks and roots, while Queen of Night contained more in the seeds.

Unsaturated fatty acids was at $88.92 \%$ in the seeds of Queen of Night and $88.62 \%$ in the seeds of Evening Scent. For other parts of the herb, this value varied from
$59.65 \%$ in Evening Scent cultivar roots, to $68.73 \%$ in Queen of Night cultivar stalks, making an average of $65 \%$.

Foreign literature sources depict fatty acid composition of Matthiola bicornis (Sibth. \& Sm.) DC seeds as follows: myristic (0.1-0.4\%), palmitic (6.0-12.0\%), palmitoleic $(0.2-0.8 \%)$, stearic $(2.3-3.0 \%)$, oleic $(14.0-14.3 \%)$, linoleic (8.3-12.0\%), linolenic (60.0-66.0\%), eicosanoic $(0.1 \%)$, gondoic $(0.1 \%)$, eicosadienoic $(0.1 \%)$, behenic $(0.1 \%)$ and epoxy-18:2 (2.5\%) fatty acids [1]. No data is found in accessible literature sources as regards the fatty acid content in other parts of the Night-scented stock herb. A comparison of the above data with the results of our research shows that the quantitative content of fatty acids was more or less equal. As to the qualitative composition, we found in the Ukraine-grown herb, the presence of myristoleic, erucic and lignoceric acids that were not identified in the foreign-origin herb. Moreover, while research elsewhere identified gondoic, eicosanoic, eicosadienoic and epoxy-18:2 fatty acids in the herb, these were not found in the Ukraine-sourced plants that we studied. With $23.0-31.5 \%$ fatty oil per dry weight in the seed [1], Matthiola bicornis (Sibth. \& Sm.) DC has potential as a new oil crop.

\section{CONCLUSION}

1. Qualitative composition and quantitative content of fatty acids were determined by gas chromatography to threshed grass, stalks, roots and seeds of Night-scented stock cultivars Queen of Night and Evening Scent as cultivated in Ukraine.

2. Both tested cultivars of Night-scented stock had identical fatty acid composition, and 12 fatty acids for each cultivar were identified in their threshed grass, stalks and roots, and 11 fatty acids in their seeds. The ratio of identified polyunsaturated, monounsaturated and saturated acids was 2:5:4 for the seeds and 2:5:5 for all other parts of the herb.

3. The polyunsaturated and monounsaturated fatty acids demonstrated quantitative prevalence among the identified fatty acids - as much as $88.92 \%$ and $88.62 \%$ in the seeds of Queen of Night and Evening Scent cultivars, respectively and $65 \%$ at an average in the other parts. Among the polyunsaturated fatty acids, linoleic and linolenic acids dominated, whereas oleic acid was of greater prevalence among the monounsaturates.

4. A comparison of the results of our research with the data from foreign literature sources gives grounds for the conclusion of a mostly similar quantitative content of fatty acids.

5. The results of our research bring about the suggestion that Night-scented stock herb be investigated as a source of polyunsaturated fatty acids for the development of drugs, as well as its use for standardization of tested raw materials.

\section{CONFLICTS OF INTEREST}

The authors declare no conflict of interest. 


\section{ORCID iDs}

Viktoriia Pinkevych (Dhttps://orcid.org/0000-0002-0166-754X Moeen F. Dababneh (Dhttps://orcid.org/0000-0002-8995-4059 Nadiia Burda (Dhttps://orcid.org/0000-0002-7435-5731

Iryna Zhuravel (1)https://orcid.org/0000-0001-8092-733X

\section{REFERNCES}

1. Glick NR, Fischer MN. The role of essential fatty acids in human health. J Evid-Based Complementary Altern Med. 2013;18(4):268-89.

2. Makarova SG, Vishneva EA. Long-chain polyunsaturated $\omega-3$ and $\omega-6$ fatty acids as essential nutrients in different periods of childhood. Pediatricheskaya farmakologiya (Pediatric pharmacology). 2013;10(4):80-8.

3. Ristić-Medić D, Vučić V, Takić M, Karadžić I, Glibetić M. Polyunsaturated fatty acids in health and disease. J Serb Chem Soc. 2013;78(9):1269-89.

4. Sokoła-Wysoczańska E, Wysoczański T, Wagner J, Czyż K, Bodkowski R, Lochyński S, Patkowska-Sokoła B. Polyunsaturated fatty acids and their potential therapeutic role in cardiovascular system disorders - a review. Nutrients. 2018;10(10):1561-82.

5. Davidyan OV, Vorslov LO. Omega-3 polyunsaturated fatty acids as a source of longevity. Vopr dietol (Nutrition). 2017;7(1):36-41.

6. Chekman IS, Gorchakova NA, Rudenko AV, Kurik MV, Orlov AA, Zagorodny MI, Osinnia LM. Clinico-pharmacological properties of polyunsaturated fatty acids (review of literature and own data). Zhurn NAMN Ukrayiny. 2013;19(3):286-96.

7. Rozhdestvenskij DA, Bokij VA. Clinical pharmacology of omega-3 polyunsaturated fatty acids. Mezhdunarodnye obzory: klinicheskaja praktika izdorov'e. 2014;3(9):121-34.
8. Shysh AM, Frantsuzova SB, Nagibin VS, Moibenko AA. Mechanisms of cardioprotective effect of omega-3 polyunsaturated fatty acids in acute damage of myocardium under immobilization stress. Farmakologiya ta likars'ka toksikologiya. 2013;2(33):76-83.

9. Fabian CJ, Kimler BF, Hursting SD. Omega-3 fatty acids for breast cancer prevention and survivorship. Breast Cancer Research. 2015;17(1):62-73.

10. Ketsa OV, Marchenko MM, Shmarakov IO. Effect of $\omega-3$ polyunsaturated fatty acids on the functional activity of monooxygenase system in the liver microsomal fraction of tumorbearing rats. Fiziologichnyi Zhurnal. 2018;64(2):19-25.

11. Azimova SS, Glushenkova AI, Vinogradova VI. (eds) Lipids, lipophilic components and essential oils from plant sources. Springer; 2012:992.

12. Karaman S, Gulseven M, Comlekcioglu N, Ilcim A. Fatty acid composition of Matthiola longipetala ssp. bicornis from Turkey. Int J Agric Biol. 2011;13(4):581-5.

13. Lim TK. (ed). Edible medicinal and non-medicinal plants. Vol. 7: Flowers. Springer;2014:1115.

14. Yaniv Z, Schafferman D, Zur M, Shamir I. Evaluation of Matthiola incana as a source of omega-3-linolenic acid. Ind Crops Prod. 1997;6:285-9.

15. Fedosov AI, Kyslychenko VS, Novosel OM. Determination of fatty acid composition of garlic leaves and bulbs. Med Clin Chem. 2019;19(4):5-9.

16. Kyslychenko OA, Protska VV, Zhuravel IO. The studies of fatty acids of the thalloms of Parmelia perlata. Fitoterapiya. Chasopys. 2017;4:40-3. 